\title{
UTILIZATION OF SAWMILL SLABS AND EDGINGS
}

\author{
BY R. L. SEABORNE
}

\author{
Mersey Paper Company, Limited, Liverpool, Nova Scotia
}

The experience of the writer in the utilization of sawmill slabs and edgings dates only from 1946 when the Mersey Paper Company decided to utilize sawmill waste in their manufacturing process. During the year 1946 considerable groundwork was done in contacting various sawmills, with the result that by the fall of 1946 a reasonable supply was being delivered.

During 1947 approximately 9,000 cords, stacked measure, of spruce and fir slabs were received and converted to approximately 6,400 cords of prepared wood.

Referring to the publication, "Spruce Waste in Sawmills of Quebec and the Maritimes", by J. B. Prince, and applying the conversion factors as shown by Mr. Prince in Table 1 to the total production of spruce and fir softwood lumber in Nova Scotia, there should be approximately 230,000 cords of slabs and edgings. The Nova Scotia Department of Lands and Forests quotes the total softwood lumber produced in 1947 at approximately 395 million board feet, of which probably 90 per cent would be spruce and fir, or approximately 340 million to 350 million feet. Using a conversion factor of .7 cords per thousand of sawn lumber as a factor to convert the total Nova Scotia production, there would be approximately 230,000 cords of slabs and edgings produced. The specification of the company is such that only approximately 50 per cent to 75 per cent of the total slabs and edgings produced by our sundry suppliers are suitable to meet the company's specification. As the slabs and edgings purchased are used for the manufacture of groundwood pulp in our magazine grinders, the specifications require that they be four feet in length and the minimum top size at the small end one inch in thickness inside the bark for slabs and one inch by two inches inside the bark at the small end for edgings.

The volume of 9,000 cords, stacked measure, received by Mersey Paper Company Ltd. during 1947 would indicate that the price of $\$ 7.00$ f.o.b. cars, shippers point, is interesting only 10 per cent or 12 per cent of those producing slabs and edgings.

The total cost of the slab barking plant is comparatively low-the conveyor system and railway spur to the plant amounted to $\$ 44,084$. In general, the plant consists of ten so-called fiddlehead barkers, Waterous type, individually belt-driven from below by a 5 to $71 / 2$ h.p. motor. A bolter is also provided to break down the large size slabs which are difficult to handle on the barkers. All waste from barking is belt-conveyed to the bark disposal plant and blown to a Dutch Oven in the boiler house.

The barking operation is carried out by piece work based on an arbitrary unit of unprepared wood. The costs of this operation during the first seven months of 1948 are as follows:

1. Paper presented at the fortieth annual meeting of the Canadian Society of Forest Engineers, Fredericton, N.B., October 4 to $7,1948$. 
TABLE 1

\begin{tabular}{|c|c|}
\hline & Per Cord \\
\hline $\begin{array}{l}\text { Slabs (Purchase Price plus estimated freight and unload- } \\
\text { ing) } \quad \ldots \ldots \ldots \ldots \ldots \ldots \ldots \ldots \ldots \ldots \ldots \ldots \ldots \ldots \ldots\end{array}$ & $\$ 15.000$ \\
\hline Direct Cost & \\
\hline Labour handling & $\$ 2.373$ \\
\hline Labour barking. & $\$ 5.092$ \\
\hline Labour repairs ... & $\$ \quad .122$ \\
\hline Material repairs. & .116 \\
\hline Lubricants ..... & .000 \\
\hline Miscellaneous supplies $\ldots \ldots \ldots \ldots \ldots \ldots \ldots$ & $\$ \quad .054$ \\
\hline Total Direct Cost $\ldots \ldots \ldots \ldots \ldots \ldots \ldots \ldots$ & $\$ 7.757$ \\
\hline Indirect Cost & \\
\hline Pro Rated Charges & .293 \\
\hline Total Indirect Cost .... & $\$ .293$ \\
\hline Total Conversion .. & $\$ 8.050$ \\
\hline Total Cost . . . . . . . & $\$ 23.050$ \\
\hline
\end{tabular}

Distribution

To Prepared Wood ................... \$23.050

Total cords prepared wood affected ........ 3,564

The prepared slabs are conveyed on regular pulpwood conveyors to the block bins and are utilized along with round wood in the preparation of newsprint grade groundwood.

Numerous tests have been made on the yield of prepared wood from a stacked cord of slabs and edgings. Table 2 is a sample of the findings, which would indicate that the loss in volume in cleaning is approximately 22 per cent, and the loss in weight in cleaning is approximately 28 per cent.

TABLE 2

Measurement of Slabs and Edgings

Supplier A $\quad$ B $\quad$ C $\quad$ D

1. Date of Test.. Jan.8/47 Jan 10 Jan.17 Jan.20

2. Car Number. $402354 \quad 501129 \quad 521279 \quad 508302$

3. Wt. Wood

in Car ..........

31,100

in Car (128

cu. ft. stacked measure)

5. Cords scaled in

Rack (128 cu. ft. stacked measure) $\ldots \ldots \ldots \ldots \ldots$

6. Est. Equiv. cords in car. .

7. Wt. Rough Wood per cord ......................
$89,800 \quad 78,400 \quad 68,900 \quad 49,500 \quad 63,540$

12.2

20.4

18.

16.3

$15.7 \quad 16.56$

$\begin{array}{llllll}1.000 & 1.000 & 1.000 & 1.000 & 1.000 & 1.000\end{array}$

$\begin{array}{lllllll}0.974 & 0.974 & 0.974 & 0.974 & 0.974 & 0.974\end{array}$

$\begin{array}{llllll}3129 & 4980 & 5027 & 4837 & 3435 & 4282\end{array}$ 
8. Cords Cleaned Wood-

Rack (128 cu. ft. stacked

$\begin{array}{lllllllll}\text { measure) } & \ldots \ldots \ldots \ldots \ldots & 0.766 & 0.750 & 0.773 & 0.797 & 0.821 & 0.781\end{array}$

9. Vol. lost in Cleaning \% $23.4 \% \quad 25.0 \% \quad 22.7 \% \quad 20.3 \% \quad 17.9 \% \quad 21.9 \%$

10. Wt. Cleaned Wood .... $2372 \quad 3745 \quad 2987 \quad 3550 \quad 2508 \quad 3032$

12. Moisture $\ldots \ldots \ldots \ldots \ldots .19 .8 \quad 51.9 \quad 50.7 \quad 40.1 \quad 18.0 \quad 36.1$

11. Wt. Lost in Cleaning \%o. $24.2 \% \quad 24.8 \% \quad 40.6 \% \quad 26.6 \% \quad 27.0 \% \quad 28.6 \%$

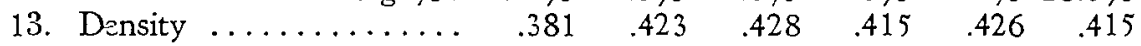

14. Remarks

\begin{tabular}{|c|c|c|c|}
\hline $\begin{array}{l}\text { Wood dry } \\
E \text { small } \\
75 \% \\
\text { slabs }\end{array}$ & $\begin{array}{l}\text { Wood green } \\
75 \% \\
\text { edgings }\end{array}$ & $\begin{array}{l}\text { Wood } \\
\text { large } \\
\text { green, } \\
75 \% \\
\text { slabs }\end{array}$ & $\begin{array}{l}\text { Wood } \\
\text { large } \\
\text { green, } \\
75 \% \\
\text { slabs }\end{array}$ \\
\hline
\end{tabular}

Item No. 9-Volume lost in cleaning \% indicates what may be expected as loss in cleaning.

Item No. 11-Weight lost in cleaning is used as a check against No. 9 and also to indicate possible amount of fuel delivered to "Dutch" oven in boiler house.

It is interesting to note from this experience that, while the cost of slabs and edgings is $\$ 7.00$ f.o.b. shippers point, the cost of prepared wood as delivered to the black bin conveyors is $\$ 23.00$ per cord, 85 cubic feet solid.

The company's experience in grinding slabs in the magazine grinders mixed with a regular run of spruce and fir has been entirely satisfactory and the loss in shims and slivers is apparently not materially greater than the shims and slivers produced in round wood.

It would appear from the foregoing that, when slabs and edgings are available at a price which, after cleaning, is competitive with prepared round wood, then such an operation is entirely feasible and provides an example of good utilization. 